\title{
ENSENYAR A ARGUMENTAR CIENTÍFICAMENT: UN REPTE DE LES CLASSES DE CIẼNCIES
}

\author{
SARDÀ JORGE, ANNA i SANMARTÍ PUIG, NEUS \\ Departament de Didàctica de la Matemàtica i de les Ciències Experimentals. UAB \\ E-mail: asarda@dewey.uab.es - neus.sanmarti@uab.es
}

\begin{abstract}
SUMMARY
In this paper a review of the main features of a scientific argumentative text is made. A reference framework and a methodological analysis of the difficulties of a group of students are proposed. Finally, educational proposals are generated to help students learn how to write argumentative texts in science lessons, in order to improve their scientific knowledge.
\end{abstract}

\section{INTRODUCCIÓ}

El professorat de ciències constata sovint les grans dificultats de la majoria d'estudiants a l'hora d'expressar i organitzar un conjunt d'idees en un escrit que es caracteritzi, des del punt de vista científic, pel rigor, precisió, estructuració i coherència.

Entre altres aspectes, es poden comprovar les dificultats per diferenciar fets observats i inferències, a identificar els arguments significatius i a organitzar-los de forma coherent. Tampoc no distingeixen entre els termes d'ús científic i els d'ús quotidià, i utilitzen paraules «comodí» pròpies del llenguatge col·loquial. A més, sovint, o bé escriuen llargues oracions amb dificultats de coordinació i subordinació, o bé de molt curtes sense justificar cap afirmació.

Moltes vegades és difícil de precisar si les dificultats es deuen a una mala comprensió dels conceptes necessaris per respondre a la demanda de l'ensenyant o a un nodomini del gènere lingüístic corresponent a la demanda. Per exemple, Halldén (1988) detecta que les connotacions teleològiques $\mathrm{i}$ antropomòrfiques en les expli- cacions de l'alumnat en el camp de la biologia es troben quan se'ls demana argumentar -i no en el nivell declaratiu. Suggereix que el problema transcendeix l'àmbit dels coneixements conceptuals i, en canvi, es situa a l'àmbit metacognitiu de saber què entenen els alumnes per explicar. En paraules de Lemke (1997), es podria dir que molts dels problemes d'aprenentatge de l'alumnat es deuen a un desconeixement tant del «patró temàtic» com del «patró estructural» propi del tipus de text científic demanat i de les interelacions entre ells.

La hipòtesi de la nostra proposta se centra a considerar que, per tal que l'alumnat progressi en el coneixement científic, ha d'arribar a conèixer tots dos patrons, el temàtic i l'estructural, i que s'han d'ensenyar de forma conjunta. Sovint es pensa que els diferents gèneres lingüístics s'aprenen a les classes de llengua i que no són objecte d'aprenentatge a les classes de ciències, però valorem que les idees de la ciència s'aprenen i es construeixen tot expressant-les, i que el coneixement de les formes de parlar i d'escriure en relació amb aquelles és una condició necessària per a la seva evolució. A més, 
cal tenir present que el llenguatge científic té unes característiques específiques i que el seu aprenentatge es pot comparar al d'una llengua diferent de la pròpia (Sutton, 1997; Lemke, 1997).

En aquest article es fa una revisió de les principals característiques d'un text argumentatiu científic i es proposa un model d'anàlisi de les dificultats d'un grup d'alumnes amb l'objectiu de generar propostes didàctiques per ajudar l'alumnat a aprendre a elaborar aquest tipus de text a les classes de ciències.

\section{LA IMPORTÀNCIA DE L'ARGUMENTACIÓ EN CIENCIES}

Actualment s'està d'acord que, en la construcció del coneixement científic, és important el procés de negociació que té lloc entre els membres de la pròpia comunitat quan es comuniquen models i teories amb la finalitat de validar representacions sobre el món (Sutton, 1997; Duschl, 1997; Sanmartí, Izquierdo i García, 1999). En aquest procés, el raonament hi intervé de manera fonamental com a instrument per relacionar les observacions experimentals amb els models teòrics existents (Jiménez, 1998). Podríem afirmar que el discurs de les ciències es va elaborant entre el racionalisme i la retòrica de l'argumentació, en un procés que cal entendre com a continuat.

Giere (1999) entén que el raonament científic és un procés d'elecció d'entre les teories que es proposen i que competeixen per tal de destriar la que, en un moment històric determinat, presenta l'explicació més convincent per a un fenomen particular del món. En l'avaluació de les teories científiques són més importants el conjunt d'arguments i les interrelacions que s'elaboren per construir un raonament que no pas el possible procés d'inferència. Aquest procés d'elecció entre teories es pot produir si es generen interpretacions diferents d'unes dades determinades a causa de tres factors (Duschl, 1997):

a) la interpretació diferent dins de la comunitat científica;

b) els avenços tecnològics que possibiliten noves formes d'observar;

c) els canvis en els objectius de la ciència com a extensió dels problemes socials.

Però els canvis en les teories acceptades, generalment, no es produeixen de forma radical, per revolucions, com proposava Kuhn, sinó de forma gradual a través d'una cadena de raonaments, tot $\mathrm{i}$ que en ciència algunes discussions triguen anys a ser resoltes i que, de vegades, no es resolen mai. Molt sovint cal esperar força temps per demostrar que les evidències són suficients per donar força a l'argumentació i poder establir una nova teoria.

De la mateixa manera que les idees evolucionen en formular una teoria, la manera de parlar-ne també evo- luciona. Sutton (1997) assenyala que el llenguatge inicial és molt personal, amb força ús d'analogies i metàfores, i els raonaments utilitzats tenen finalitats especulatives i persuasives. En canvi, quan les idees ja estan consolidades, el llenguatge per comunicar-les esdevé més formal, impersonal, precís i rigorós, i les paraules que identifiquen les noves idees -quark, DNA, o qualsevol altra- són utilitzades com a etiquetes de quelcom que té una existència real indiscutible.

Es pot passar del primer tipus de llenguatge, el més individual, al qualificat de més «científic» perquè tots dos tenen en comú un patró de relacions de significat que descriuen el contingut científic inclòs en la primera interpretació i que es concretarà en conceptes i en un model teòric determinat. A aquest patró de vincles semàntics, Lemke (1997) l'anomena patró temàtic. El que els distingeix és el patró estructural, que es refereix al tipus de discurs. És obvi que les estructures retòriques (sil-logismes, analogies, metàfores...) i de gènere (descripció, justificació, argumentació, elaboració d'informes...) han de ser diferents en un i l'altre cas, perquè primer han de convèncer la comunitat científica i després s'han de comunicar a la resta de persones.

\section{EL PAPER DE L'ARGUMENTACIÓ EN L'APRENENTATGE CIENTIFIC}

En les diverses teories i pràctiques d'ensenyament de les ciències hi ha, més o menys implícites, formes diferents d'entendre què és la ciència, com es genera, i també les seves finalitats i les del seu ensenyament. Tots els factors exposats en l'apartat anterior defineixen una visió determinada de la ciència, de la seva construcció i de les característiques del llenguatge científic, que poden orientar una transposició didàctica una mica diferent de l'habitual a les classes de ciències.

De la mateixa manera que en la construcció del coneixement científic és important la discussió i el contrast de les idees, i que el llenguatge inicial té unes característiques diferents del final, també caldria donar molta més importància, en la construcció del coneixement propi de la ciència escolar, a la discussió de les idees a l'aula i a l'ús d'un llenguatge personal que combini els arguments racionals i els retòrics, com a pas previ, sovint necessari, perquè el llenguatge formalitzat propi de la ciència prengui tot el seu sentit per a l'alumnat.

El canvi de perspectiva és significatiu, ja que pressuposa que la manera tradicional de plantejar les classes de ciències, iniciant-les donant a conèixer els conceptes de forma ja «etiquetada», no és coherent, ni amb la forma en què es genera el coneixement científic, ni amb les tesis constructivistes de l'aprenentatge.

Els grans objectius que es pretenen assolir amb l'ensenyament-aprenentatge de l'argumentació o raonament científic, d'acord amb Driver i Newton (1997), són els següents: 
- En primer lloc, tal com hem justificat anteriorment, ajuda a desenvolupar la comprensió dels conceptes científics. En el marc de la ciència escolar és molt important la discussió dels criteris per avaluar les teories científiques, és a dir, parlar a classe de la relacions existents entre les hipòtesis, els fenòmens, els experiments, els models teòrics i l'evolució de les teories (Jiménez, 1998). L'alumnat va entrant en el món de la ciència en la mesura en què té necessitat d'utilitzar els instruments conceptuals i procedimentals que la cultura científica ha anat construint -«entitats» (Ogborn et al., 1998) com gens, cromo somes, camps elèctrics, àtoms, proporcionalitat o oscil-loscopi-per parlar i escriure (i llegir) ciència, és a dir, per comunicar-se. Però això implica, al mateix temps, aprendre a estructurar els camins de raonament, o sigui, el discurs argumentatiu, reconeixent-ne les característiques.

- En segon lloc, l'argumentació pot oferir una visió més entenedora de la pròpia racionalitat de la ciència, analitzant-ne el procés de construcció: el «context de descobriment» per a la generació d'hipòtesis i el «context de justificació» per comprovar-les i validar-les, els quals prenen sentit en un «context de coneixement» acceptat (Duschl, 1997). Si es presenta la ciència com el producte final del procés però no es reconeixen els canvis que s'hi han produït, no es podran entendre les conclusions derivades de les teories. És a dir, una forma d'aproximar-se a l'epistemologia de la ciència és aprendre a construir afirmacions $i$ arguments $i$ a establir-hi relacions coherents per interpretar els fenòmens. Això implica ensenyar a llegir ciències, a discutir teories que han estat rebutjades $i$ acceptades per la comunitat científica, a explicitar els criteris de les decisions racionals $\mathrm{i}$ el perquè unes teories ofereixen una millor interpretació que les altres.

- D'altra banda, en una societat democràtica cal formar un alumnat crític i capaç de destriar d'entre els diferents arguments que se li presenten, per tal de poder prendre decisions en la seva vida com a ciutadans. En tant que l'ensenyament de les ciències a l'escola es generalitza fins a edats avançades, la seva finalitat deixa de reduirse a preparar l'alumnat per seguir cursos universitaris i passa a ser, tal com diu Layton (1992), promoure un coneixement per a l'acció.

Bona part dels problemes de l'entorn -siguin ambientals, relacionats amb la salut o d'altres- requereixen donar opinions fonamentades científicament. Aquests problemes, a diferència dels que s'analitzen a les classes habituals de ciències, no formen part del «nucli dur» (Duschl, 1997) de la ciència, és a dir, d'aquells la solució dels quals ja ha estat consensuada i és àmpliament compartida pels membres de la comunitat científica. En canvi, és en la discussió sobre la idoneïtat dels aliments transgènics, o què fer amb els residus, o com aconseguir una millor qualitat de l'aire, quan l'alumnat pot situar-se i reconèixer el «context de descobriment» i el «context de justificació» $\mathrm{i}$ anar diferenciant entre arguments fonamentats científicament i d'altres tipus d'arguments.
Ens trobem, per tant, que l'aprenentatge de l'argumentació a les classes de ciències pren sentit des de molts punts de vista. Per aprendre ciència cal aprendre a parlar i escriure (i llegir) ciència de manera significativa. Això implica també aprendre a «parlar sobre com s'està parlant» (metadiscurs), reconeixent les diverses maneres d'expressar un mateix significat, les diferències entre el llenguatge quotidià i el científic i les principals característiques de cada tipus de discurs.

L'única manera d'aprendre a produir argumentacions científiques és produir textos argumentatius -escrits i orals- a les classes de ciències, discutint les raons, justificacions i criteris necessaris per tal d'elaborar-les (Izquierdo i Sanmartí, 1998; Jiménez, 1998). Aquest aprenentatge comporta aprendre a utilitzar unes determinades habilitats cognitivo-lingüístiques (descriure, definir, explicar, justificar, argumentar i demostrar) que, alhora, necessiten l'ús de determinades habilitats cognitives bàsiques de l'aprenentatge (analitzar, comparar, deduir, inferir, valorar...) (Prat, 1998).

\section{FORMES DE CONCEPTUALITZAR L'ARGU- MENTACIO}

En els darrers anys, diversos autors han elaborat, des de diferents punts de vista, models sobre els elements que constitueixen una argumentació, les interrelacions que cal que s'estableixin entre aquests elements perquè sigui vàlida i quines seqüències en són les característiques.

Per analitzar un discurs, segons Calsamiglia i Tusón (1999, p. 185) cal distingir entre el significat gramatical del sistema lingüístic (no té en compte els factors «extralingüístics») i el sentit o el significat discursiu (interdependència dels factors contextuals i dels lingüístics, tenint en compte el «món» del receptor, els coneixements previs i els compartits, les intencions...). En una classe, els textos elaborats per l'alumnat acostumen a dirigir-se al professorat perquè els avaluii. Aquest fet en condiciona fortament l'elaboració, tant perquè l'estudiant persegueix, més que res, endevinar què és el que l'ensenyant espera d'ell o ella com perquè hi ha parts del discurs implícites en funció de tot allò que comparteixen ambdues parts.

En aquest apartat analitzarem el discurs argumentatiu a partir de dues perspectives diferenciades: la concretada per Toulmin (1993), en la qual es planteja una revisió de l'argumentació com a teoria del raonament pràctic, i la provinent de la lingüística textual, representada pels models de Van Dijk (1978) i Adam (1992), que es planteja l'anàlisi de les unitats comunicatives que van més enllà dels límits de les oracions gramaticals.

Toulmin (1993), filòsof i epistemòleg, aporta una visió de l'argumentació des de la formalitat i la lògica. Segons ell hi ha normes universals per construir i avaluar les argumentacions que estan supeditades a la lògica formal. Elabora un model de l'estructura formal de l'argumentació: descriu els elements constitutius, representa 
les relacions funcionals entre ells i especifica els components del raonament des de les dades fins a les conclusions. El model que proposa (Fig. 1) es basa en el següent esquema de l'argumentació, que conté els components següents:

- $\mathrm{D}=$ Dades $:$ Fets o informacions factuals, que s'invoquen per justificar i validar l'afirmació.

- $\mathrm{C}=$ Conclusió: La tesi que s'estableix.

- $\mathrm{G}=$ Justificacions: Són raons (regles, principis...) que es proposen per justificar les connexions entre les dades i la conclusió.

- F = Fonaments : És el coneixement bàsic que permet assegurar la justificació.

- $\mathrm{Q}=$ Qualificadors modals: Aporten un comentari implícit de la justificació; de fet, són la força que la justificació confereix a l'argumentació.

- $\mathrm{R}$ = Refutadors: També aporten un comentari implícit de la justificació, però assenyalen les circumstàncies en què les justificacions no són certes.

Els qualificadors modals i els refutadors són necessaris quan les justificacions no permeten acceptar una afirmació de manera inequívoca, sinó provisional, en funció de les condicions sota les quals es fa l'afirmació.

Segons aquest model, en una argumentació, a partir d'unes dades obtingudes o d'uns fenòmens observats, justificats de forma rellevant en funció de raons fonamentades en el coneixement científic acceptat, es pot establir una afirmació o conclusió. Aquesta afirmació pot tenir el suport dels qualificadors modals i dels refutadors o excepcions.

Toulmin segueix una analogia entre un text argumentatiu i un organisme, de manera que la part anatòmica està constituïda per òrgans, que són les diferents fases de progrés de l'argument, des de l'enunciat inicial fins a la conclusió final; i la part fisiològica està constituïda per la lògica de cada frase. Però no es pot deslligar la fisiologia de l'anatomia: és un tot que pren sentit quan les parts s'interrelacionen entre si, és a dir, que la lògica de cada enunciat ve determinada per la seva situació en l'argumentació, i viceversa.

El model de Toulmin, adaptat a la pràctica escolar, permet reflexionar amb l'alumnat sobre l'estructura del text argumentatiu i aclarir les seves parts, destacant la importància de les relacions lògiques que hi ha d'haver. És a dir, possibilita una meta-reflexió sobre les característiques d'una argumentació científica, aprofundint sobre com s'estableixen les coordinacions i les subordinacions, sobre l'ús dels diferents tipus de connectors (adversatius, causals, consecutius...), sobre la no-linealitat dels raonaments, etc.

D'una banda, l'estudi de l'anatomia del text permet analitzar amb l'alumnat el significat de cada proposició del text per si mateixa, els tipus de seqüències que es poden establir amb aquests elements i quins tipus de connectors permeten fer el pas entre les diferents oracions del text. D'altra banda, l'estudi de la fisiologia de l'argumentació ajuda a treballar l'ús de concordances lògiques en el context de la ciència entre les diferents parts del text. Aquestes relacions de concordança es concreten en l'anàlisi de l'acceptabilitat i de la rellevància de les proposicions formulades. Totes aquestes són dificultats importants de l'alumnat (Llorens i De Jaime, 1995; Zeidler $\left.{ }^{1}, 1997\right)$, ja que solen afirmar conseqüències sense tenir en compte les justificacions teòriques. Presenten problemes per seleccionar les evidències a causa de la dificultat d'identificar els fets $\mathrm{i}$ fenòmens $\mathrm{i}$ distingir-los de les interpretacions o dels models individuals o bé estableixen inferències que van més enllà dels límits que presenten els mateixos fets i fenòmens.

Tanmateix, tal com indiquen Driver i Newton (1997), el model toulmià presenta el discurs argumentatiu de forma descontextualitzada sense tenir en compte que depèn del receptor i de la finalitat amb la qual s'emet. Per tant, és útil per prendre consciència de l'estructura d'una argumentació però no de la seva validesa.

Figura 1

Esquema del text argumentatiu, segons Toulmin (1993).

\begin{tabular}{|c|c|c|c|}
\hline $\begin{array}{c}\text { DADES (D) } \\
\text { ja que } \\
\text { JUSTIFICACIÓ }(\mathrm{G}) \\
\text { a causa que } \\
\text { FONAMENTACIÓ }(\mathrm{F})\end{array}$ & per tant, & $\begin{array}{c}\text { QUALIFICADOR } \\
\text { MODAL (M) } \\
\qquad \begin{array}{c}\text { excepte si } \\
\text { REFUTADORS (R) }\end{array}\end{array}$ & CONCLUSIÓ (C) \\
\hline
\end{tabular}


Figura 2

Superestructura argumentativa, segons Van Dijk (1978).

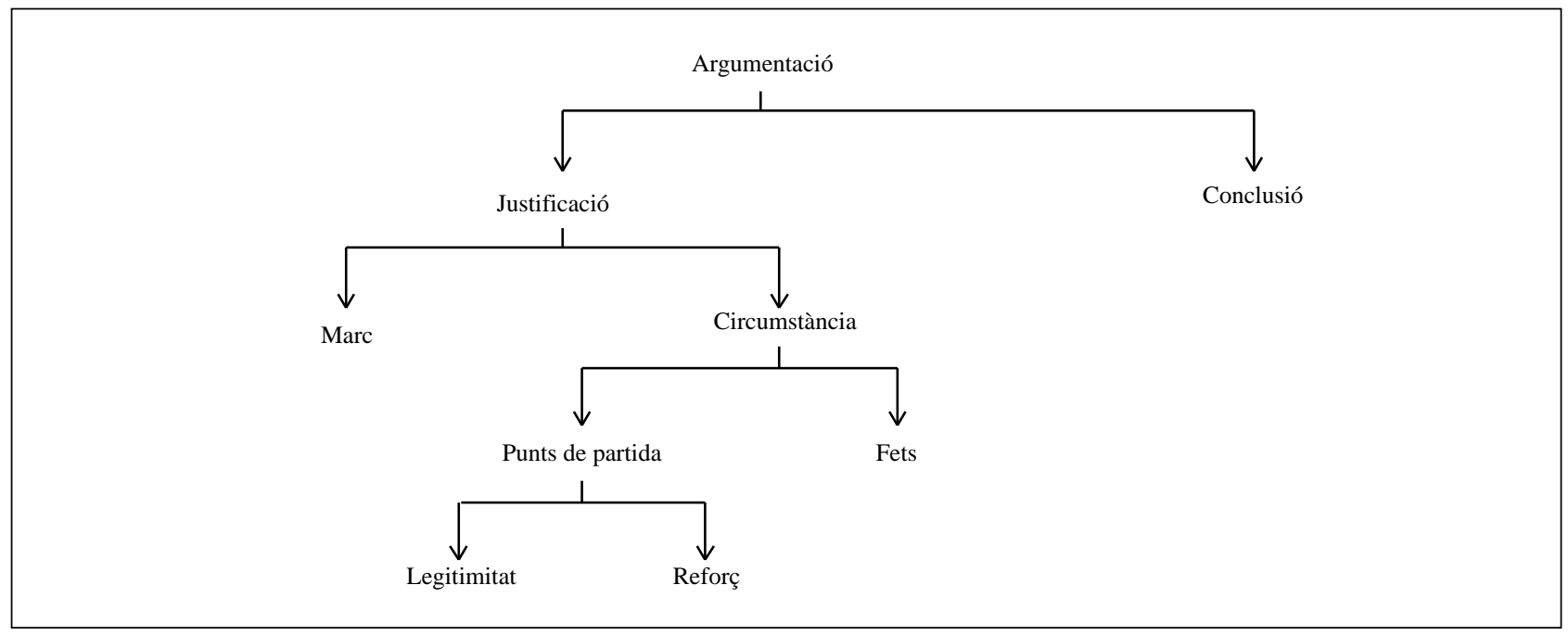

Des de l'àmbit de la lingüística textual, Van Dijk (1978) aporta un altre model conceptual de l'argumentació (Fig. 2). Segons ell, el que defineix un text argumentatiu és la seva finalitat: convèncer una altra persona.

Segons aquest model, els components fonamentals són la justificació i la conclusió. La justificació es construeix a partir d'un marc general, en el context del qual prenen sentit les circumstàncies que s'aporten per justificar les conclusions. Aquestes circumstàncies es refereixen a fets i a condicions inicials o punts de partida que l'emissor considera que són compartits pel receptor. En el context de l'aula, per exemple, no seria vàlid, normalment, que un alumne reforcés un argument dient «tal com ho va dir Newton»; fet que, en canvi, sí que seria acceptable en el context d'un article científic. O en una classe de 1r d'ESO, si es parla de «dissolució», s'espera que l'alumnat desplegui el que entén per aquest concepte, mentre que en una classe de batxillerat es pot considerar que bona part dels fets i punts de partida ja formen part del coneixement compartit per estudiants i professorat. En un cas i en l'altre, les circumstàncies seran diferents i, per tant, l'argumentació construïda també.

Per altra banda, aquest autor fa una aproximació als trets estructurals resultants de les operacions cognitives que es posen en joc a l'hora d'escriure qualsevol tipus de text tot distingint-hi la microestructura, la macroestructura $i$ la superestructura. El model de Van Dijk resulta força interessant per treballar a l'aula el text argumentatiu. Per una banda, la idea de la macroestructura en una argumentació permet de treballar amb l'alumnat la importància que la seqüència d'oracions establerta ha d'estar destinada a justificar i raonar una tesi amb la finalitat $i$ intencionalitat de convèncer els companys i companyes.
L'atenció a la superestructura permet analitzar els conceptes sobre un tema determinat $i$ les seves interrelacions, així com els diferents tipus de connectors o elements gramaticals que fan explícites aquestes relacions. El fet que la intenció comunicativa del text respongui a convencions socials pot ajudar a treballar les normes d'una societat democràtica, basada en el diàleg i la comprensió dels altres, en la qual no hi hauria d'haver lloc per a les fal-làcies ni els enganys.

Per últim, treballar la microestructura del text argumentatiu pot ajudar a superar les múltiples dificultats que les noies i els nois manifesten en aquest aspecte (Llorens i De Jaime, 1995), ja que permet aprofundir en l'ús d'oracions subordinades causals, consecutives, adversatives, condicionals... i les respectives conjuncions, de manera que s'expliciten més les relacions lògico-argumentatives. També permet analitzar l'ús dels substantius de forma més precisa i subjectes més abstractes, enfront dels termes «comodí» del llenguatge quotidià; i la utilització de les oracions passives i impersonals, enfront de l'ús de l'indicatiu i les primeres formes personals. En resum, creiem que aquesta visió de l'organització dels textos de Van Dijk pot ser útil a les classes de ciències per acostar l'alumnat, de forma progressiva, a les característiques pròpies del llenguatge científic.

Finalment, analitzarem el model d'un tercer autor, Adam (1992), també lingüista, que aporta la idea de la funció persuasiva que té l'argumentació, un model de seqüència textual i un model del prototipus del text argumentatiu (Fig. 3). Concretament, la noció de prototipus de text ha estat útil, sobretot, en l'anàlisi dels textos del primer estudi elaborat, especialment pel que fa a redefinir la noció de superestructura de Van Dijk, i distingir-ne 


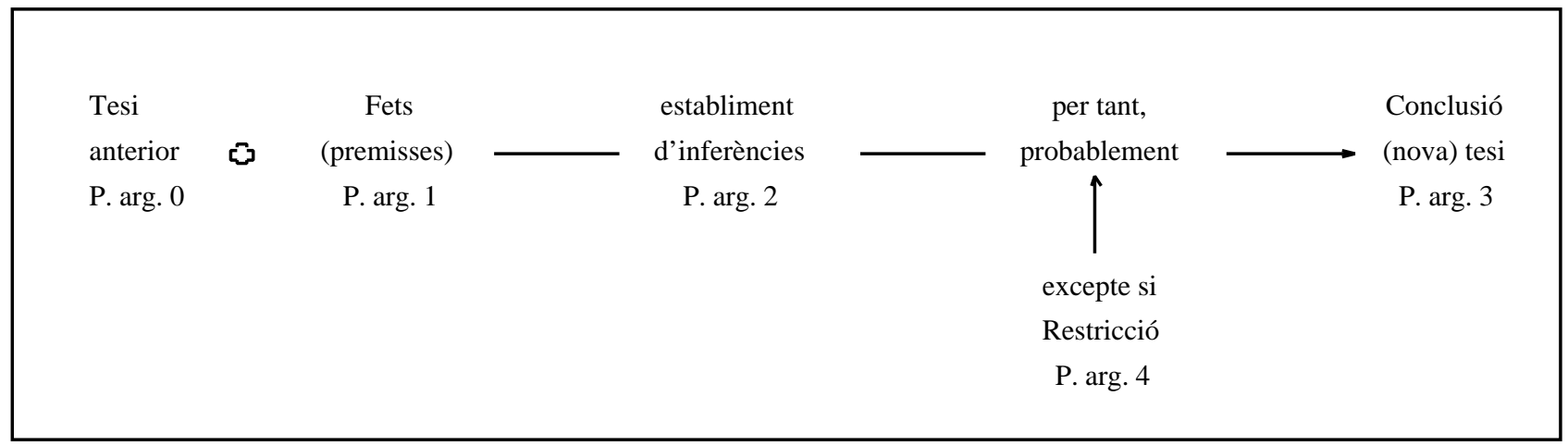

dues dimensions: la pragmàtica (que fa referència a la intencionalitat, al marc de referència dels enunciats i a la cohesió semàntica global -equivalent a la macroestructura de Van Dijk-) i la seqüencial (que fa referència a la gramàtica del text -equivalent a la microestructura de Van Dijk-i a l'organització de les diferents seqüències del text; diferent segons cada persona).

Segons Adam, un text pot estar estructurat en diferents seqüències de base (en la fig. 3, les macroproposicions P. arg. 1, 2 i 3), tot i que existeix la possibilitat que s'estructuri de manera única. En tot cas, però, sempre hi ha un tipus de seqüència que destaca i que defineix l'estructura dominant del text. Per exemple, en una argumentació hi tenen cabuda seqüències introductòries descriptives, narratives o d'altres tipus, però globalment la seqüència que predomina és l'argumentativa, amb les seves pròpies característiques, i al lector o oient és aquest el missatge que li arriba. Un text determinat, doncs, es pot considerar com a argumentatiu si s'aproxima a aquest prototipus. Aquesta noció és important perquè ni el professorat ni l'alumnat no hauríem de caure en la rigidesa de l'estructura del text -fet que podria succeir si s'ensenya el model toulmià de forma mecanicista- per tal de no eliminar-ne la creativitat i per analitzar-lo d'una forma més flexible. En paraules d'Adam (1992, p. 19), «chaque texte est une réalité beaucoup trop hétérogène pour qu'il soit possible de l'enfermer dans les limites d'une définition stricte».

Adam recull el model de Toulmin com a base de l'estructura argumentativa, però analitza els textos com a seqüències argumentatives encadenades en què es pot produir el cas que la conclusió d'una seqüència sigui la premissa de la següent. Considera que, per validar les raons i conclusions que s'exposen en un text, s'utilitzen unes regles d'inferència que molt sovint són implícites. Creiem que una tasca molt important a fer amb l'alumnat a les classes de ciències és fer explícites aquestes regles per tal d'ajudar a entendre les relacions entre els conceptes des del punt de vista científic, la validesa dels raonaments i la seva rellevància.

\section{METQDOLOGIA I INSTRUMENTS PER A L'ANÁLISI}

\section{Mostra i recollida de dades}

En l'estudi que vam realitzar es va demanar a l'alumnat que argumentés, en el marc d'un joc de rol (Sardà, 1999; Pujol, Sardà i Rodríguez, 1998), sobre quatre mètodes diferents de conservació dels aliments que havien estat objecte d'ensenyament en sessions de classe anteriors. Cada grup havia de defensar una tècnica i partien de diferents «fets» o dades que se'ls donaven.

Els estudiants van elaborar textos escrits i orals (aquests últims improvisats al llarg de l'activitat) després d'haver-los donat unes breus orientacions per a la redacció de textos argumentatius i un text model que permetia identificar-ne les característiques (Quadre 1). Aquests textos els van llegir (o exposar) en el marc del joc de rol i a partir d'ells es va generar una discussió en què els companys i companyes introduïen contrarguments.

La mostra, la constituïa un grup classe de 14 alumnes, format per 12 nois i 2 noies, d'entre 14 i 15 anys, de 3r d'ESO, de l'Institut Pere Calders de Cerdanyola (Barcelona). Per a aquesta recerca es van recollir les produccions individuals inicials de l'alumnat, 9 textos orals i 11 textos escrits, a través de les quals pretenien argumentar el seu punt de vista. Les transcripcions dels textos orals han estat tractades com si fossin escrites i només n'hem destacat algun aspecte que les diferencia.

\section{Primer nivell d'anàlisi: estructura dels textos}

Per tal d'estudiar aquests textos argumentatius vam dissenyar un esquema (Fig. 4) que ens permetés analitzar els escrits com a tals i el seu context. En funció d'aquest esquema, es van identificar i situar les parts de cada un dels textos elaborats (Fig. 9), com a primera reducció de les dades, per tal de facilitar després l'aprofundiment en 


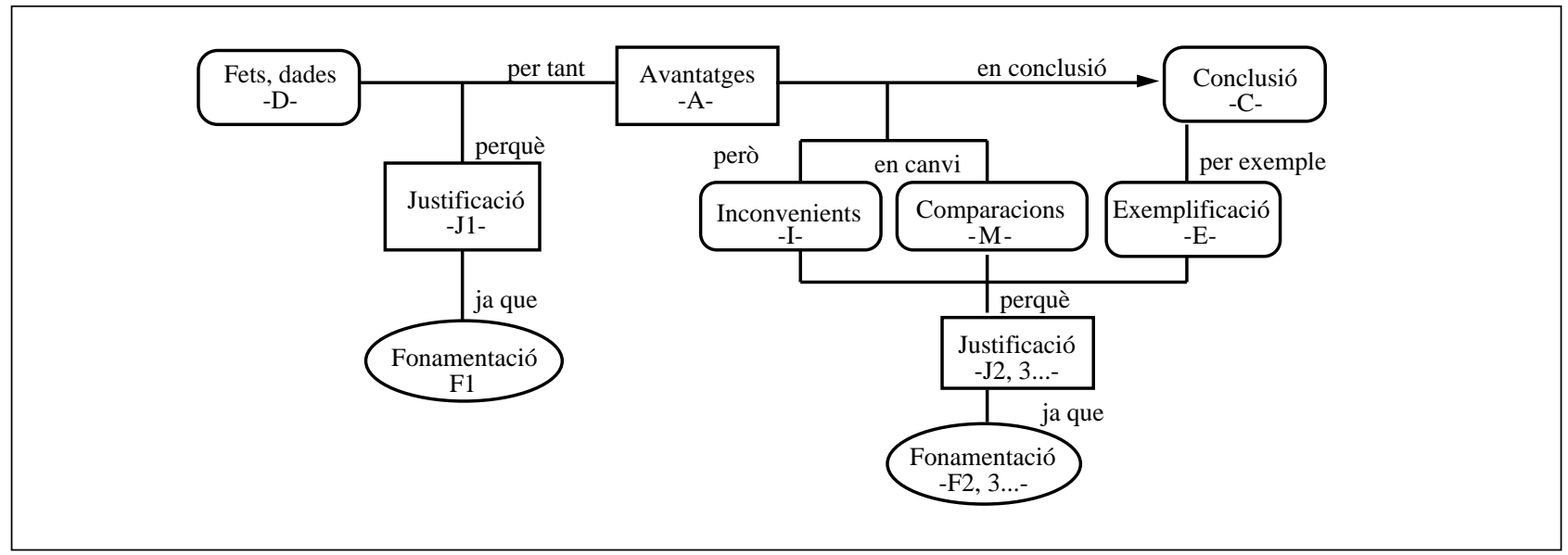

l'anàlisi de l'estructura i de les funcions i interrelacions de significat entre cada una d'elles.

L'esquema com a tal està basat en el model de Toulmin (1993) abans esmentat, adaptat al context d'aula en el qual ens trobàvem per tal d'incorporar aspectes que s'han constatat com a dificultats dels alumnes en elaborar textos argumentatius. Per altra banda, pel que fa a l'anàlisi de cada una de les parts del text, també s'han tingut en compte els aspectes provinents dels estudis de lingüística textual.

El text del quadre 1 ens serveix per exemplificar les parts que conté l'esquema elaborat, i que va ser l'exemple que es va discutir inicialment amb l'alumnat.

Quadre 1

Exemple d'un text argumentatiu.

a) El temps de conservació dels aliments esterilitzats és de diversos mesos $b$ ) perquè amb aquesta tècnica s'eliminen gairebé tots els microorganismes, $c$ ) ja que s'escalfa a temperatures molt elevades durant pocs minuts. $d$ ) Per tant, anul-lem la possibilitat que l'aliment es podreixi i es faci malbé; $e$ ) però amb aquest mètode es poden destruir part de les vitamines i modificar els sucres i les proteïnes. f) Altres tècniques de conservació també modifiquen les característiques sensorials i nutritives dels aliments; però, necessiten un temps molt llarg de preparació, com, per exemple, el salat dels pernils. $g$ ) En conclusió, l'esterilització és una bona tècnica per conservar els aliments durant força temps, que costa poc de preparar, tot i que en varia les característiques, que té molt bona sortida al mercat, i $h$ ) gràcies a aquesta podem beure llet, per exemple, sense haver-la d'anar a buscar a la lleteria cada dia.

Dades. Són els fets i fenòmens que constitueixen l'afirmació sobre la qual es basteix el text argumentatiu; en l'exemple, la proposició $a$. En el context escolar, segons Jiménez (1998), hi ha dos tipus de dades: les subminis- trades (per exemple, per algun estudi sobre el tema, pel professorat, pel llibre de text) i les obtingudes, bé sigui de forma empírica (per exemple, les procedents d'un experiment de laboratori), bé siguin dades hipotètiques.

Justificació. És la raó principal del text que permet passar de les dades a la conclusió; en l'exemple, la proposició $b$. S'ha de referir a un camp de coneixement específic, en aquest cas de la ciència-tecnologia, perquè és aquest marc el que valida el contingut de la raó.

Fonamentació. És el coneixement bàsic de caràcter teòric necessari per acceptar l'autoritat de la justificació; en l'exemple, la proposició $c$. Lògicament, també s'ha de referir a un camp de coneixement específic.

Argumentació. Proposem la distinció entre la justificació i l'argumentació, entenent que en conjunt es tracta de donar raons o arguments, però que la justificació només legitima la connexió entre l'afirmació inicial i la conclusió. En canvi, aquestes raons es construeixen de forma retòrica en relació amb altres aspectes que donen més força i criteris per a la validació del conjunt de l'argumentació. Els tres tipus d'arguments o raons que hem considerat que formen part del text argumentatiu són l'avantatge, l'inconvenient i la comparació.

Avantatge. De fet, és un comentari implícit que reforça la tesi principal; en l'exemple, la proposició $d$. Partim de la suposició que és l'argument més fàcil de formular perquè destaca els elements positius de la pròpia teoria.

Inconvenient. Comentari implícit que assenyala les circumstàncies de desavantatge; en l'exemple, la proposició $e$. Pensem que és un tipus d'argument que en les classes de ciències es treballa poc.

Comparació. En realitat, és una fusió dels dos anteriors, perquè afegeix un altre avantatge a la pròpia argumenta- 
ció i qüestiona la validesa de les altres; en l'exemple, la proposició $f$.

Conclusió. És el valor final que es vol assolir a partir de la tesi inicial i segons les condicions que inclouen els diferents arguments; en l'exemple, la proposició $g$.

Exemplificació. És la relació entre la ciència i la vida quotidiana; en l'exemple, la proposició $h$.

Pel que fa als connectors, són del tipus argumentatiu (causals, consecutius, adversatius, concessius i condicionals) entenent que manifesten la relació, des del punt de vista cognitiu, entre les idees que expressen els enunciats. En l'esquema de referència se'n proposen uns de determinats, potser els més comuns, però n'hi poden haver molts més (Calsamiglia i Tusón, 1999, pp. 248, 299).

\section{Segon nivell d'anàlisi: anatomia $i$ fisiologia dels textos}

En segon lloc, seguint l'analogia de Toulmin, i en el marc de la fonamentació teòrica exposada anteriorment, hem considerat que l'anàlisi dels textos argumentatius de l'alumnat ja reduïts seguint la figura 4 es podia realitzar a partir de:

- «Anatomia», analitzada segons tres ítems que s'han estimat com els més rellevants: validesa formal, sequiència i connectors.

- «Fisiologia», segons sis ítems: concordança entre els fets i la conclusió, acceptabilitat de la justificació principal, rellevància dels tres tipus d'arguments -avantatge, inconvenient i comparació- i exemplificació.

Aquests ítems han estat codificats, en una segona reducció de les dades, en xarxes sistèmiques, com proposen Bliss i els seus col-laboradors (1983). En la descripció que es fa a continuació d'aquests ítems creiem que és important destacar que s'han tingut en compte els implícits perquè són els que guien les inferències que han de fer els participants en l'acte comunicatiu per tal d'interpretar correctament els significats. Aquests implícits són un component molt important de tenir en compte en l'anàlisi de l'argumentació plantejada, perquè no es pot deixar de banda el context en el qual s'elabora el discurs -escrit o oral-(Llorens i De Jaime, 1995). Per exemple, tots els professors estem acostumats a «llegir entre línies» un text d'un alumne i reconèixer allò que vol dir però que no diu.

\section{Descripció dels ítems}

\section{En relació a l'anatomia del text argumentatiu}

\section{Validesa formal del text}

S'entén per validesa formal la presència dels diferents components del text, seguint l'esquema de la figura 4, sense tenir en compte els connectors que els introduei- xen, ni la sequiència dels components, ni la rellevància o pertinència dins el text. Es considera que un text argumentatiu és complet si presenta tots els components essencials com a mínim, bé sigui de forma explícita, bé sigui de forma implícita. S'han considerat com a components essencials: el fet, la justificació i la conclusió -seguint els models d'argumentació- sense els quals el text no és vàlid. En el context de l'activitat que es va realitzar també s'ha inclòs com a element essencial mínim un dels tres tipus d'arguments (avantatge, inconvenient o comparació). Cal destacar que, en l'exemple que es va discutir amb l'alumnat, previ al joc de rol, potser no va quedar suficientment clar el paper de la fonamentació de la justificació principal. La resta de justificacions i fonamentacions secundàries no se'ls va demanar que les explicitessin, però s'han inclòs en l'anàlisi perquè hi apareixen de forma explícita en molts casos. Com es pot veure, no s'han tingut en compte la possible justificació ni fonamentació de l'argument avantatge, perquè entenem que -seguint Toulmin (1993)sovint indica allò que s'infereix de la mateixa justificació principal, com a primera deducció del fet-justificació. Per tant, el fet de justificar-lo o fonamentar-lo podria resultar tautològic.

\section{Seqüència textual}

Tal com ja s'ha indicat, en l'activitat que es va desenvolupar a l'aula, per tal d'ajudar l'alumnat a aprendre a argumentar, es va presentar un text «exemple» que presentava una determinada seqüència progressiva, és a dir, que parteix de les premisses per arribar a la conclusió (Quadre 1). En aquest ítem s'analitzen els tipus de seqüències que va elaborar l'alumnat en funció de la presentada. Un text que no presenta connectors, ni de forma explícita ni implícita, es considera que no segueix cap tipus de seqüència. En cada cas, s'analitzen les parts de la sequiència, és a dir, quins components del text hi apareixen i quins no, i la connexió o no entre aquests components. S'han tingut en compte de forma separada les seqüències que presenten el component exemplificació (relació amb el món quotidià), donat que es va detectar la dificultat que suposava per a l'alumnat. L'anàlisi de la relació existent entre els arguments avantatge i inconvenient és deguda a la nostra suposició, com hem dit anteriorment, que és més fàcil de formular els aspectes positius de la pròpia teoria, que no pas els negatius, quan es vol convèncer algú.

\section{Connectors}

Ja s'ha esmentat la importància dels connectors en un text perquè són aquests els que ajuden a determinar la microestructura del text, a conformar-ne la superestructura i, globalment, permeten fer-se una idea de la macroestructura. En alguns estudis (Llorens i De Jaime, 1995) es mostren les dificultats de l'alumnat per establir connexions de coordinació i subordinació, que afecten tant a la microestructura del text com a la macroestructura, fet que dificulta la lectura global i el reconeixement de l'estructura lògica. En aquest ítem s'analitza el tipus de connectors que apareixen en les produccions de l'alumnat, bé explícits, bé implícits, i l'ús adequat o no que en 
fan. Així, s'estudia tant en quina mesura l'alumnat utilitza els connectors del text model com la seva presència explícita o implícita. Alguns treballs (Calsamiglia i Tusón, 1999) mostren que en els textos argumentatius, com més estructurats són, més connectors implícits s'hi troben, perquè moltes de les relacions entre els components del text vénen ja donades per la mateixa superestructura. És a dir, que la coherència i la lògica del text no vénen determinades tant pels connectors, sinó per les relacions i connexions de significat existents entre les idees. Tot i així, un text argumentatiu es defineix per l'ús de connectors del tipus lògico-argumentatius $i$, per aquest motiu, hem analitzat si el seu ús és el més adequat en la connexió dels components dels textos. En canvi, no s'ha analitzat l'ús de possibles marcadors lingüístics que organitzen el text.

\section{En relació a la fisiologia del text argumentatiu}

\section{Concordança entre els fets i la conclusió}

Els fets constitueixen l'afirmació sobre la qual es basteix el text argumentatiu i orienten des del primer moment el pas a la conclusió. És lògic afirmar que entre la tesi inicial i la conclusió final hi ha d'haver una concordança tal que permeti validar tota l'argumentació. És a dir, que, si no existeix una connexió epistemològica entre els fets i la conclusió, el text argumentatiu no és vàlid. Aquesta relació pot semblar immediata i de simple lògica formal, però ni per a l'alumnat ni per als científics és tan obvia. Les lleis, les teories, els principis, els models... són conclusions a les quals s'arriba al llarg d'un procés que implica l'establiment dels fets a partir de les dades, i al final del qual aquestes dades prenen significació en la conclusió (Duschl, 1997). Quan s'ensenya a l'alumnat el raonament científic i l'establiment de les teories, aquestes dificultats són importants i l'alumnat cau sovint en l'ús de tautologies, com mostren altres estudis (Llorens i De Jaime, 1995; Sanmartí, 1997). Per aquestes raons, en aquest ítem s'analitzen les concordances entre els fets formulats i les conclusions establertes. Es considera que les conclusions es poden establir a partir de tres perspectives: des del punt de vista teòric utilitzant termes provinents del context científic, des del punt de vista dels mateixos fets o des del punt de vista purament descriptiu (Izquierdo i Sanmartí, 1998). Per altra banda, s'analitza l'ús de les tautologies, segons si s'han formulat en els mateixos termes que en l'afirmació inicial o en termes diferents.

\section{Acceptabilitat de la justificació principal}

Justificar és, segons Jorba (1998, p. 48) «produir raons o arguments, establir relacions entre ells i examinar la seva acceptabilitat amb la finalitat de modificar el valor epistèmic de la tesi des del punt de vista del destinatari». Molts estudis (Llorens i De Jaime, 1995; Custodio i Sanmartí, 1997) mostren les dificultats de l'alumnat per justificar, per fer el pas de les justificacions relacionades amb la vida quotidiana a les justificacions científiques. Per analitzar aquesta acceptabilitat hem utilitzat els conceptes de pertinença i coherència de Calsamiglia i Tusón (1999) en el context de la ciència escolar. Per tant, s'examina que les raons siguin pertinents en relació amb la ciència-tecnologia o amb el coneixement empíric construït a partir de la vida quotidiana, que siguin coherents amb la ciència i que permetin establir les inferències adequades. Però no es pot oblidar que l'alumnat troba vàlids els coneixements que ha anat adquirint en l'experiència de cada dia, siguin científics o no $i$, per tant, es considera la justificació acceptable des d'aquest punt de vista. Segons el tipus de pertinença, doncs, l'argumentació tindrà més o menys força i permetrà arribar o no a la conclusió final. Per altra banda, ja s'ha esmentat que es necessiten uns criteris per tal que la pertinença de la justificació sigui vàlida. Aquests criteris els proporciona la fonamentació de la justificació. Pels mateixos motius que s'acaben d'exposar, les fonamentacions que produeix l'alumnat poden provenir tant del coneixement científic com del context de la vida quotidiana. En aquest cas, però, les fonamentacions poden resultar incoherents amb la justificació.

6, 7, 8. Rellevància dels arguments: avantatge, inconvenient i comparació

Ja s'ha exposat la distinció que es proposa entre la justificació i l'argumentació en els textos argumentatius. L'argumentació no legitima només la concordança entre els fets i la conclusió, sinó la validesa total del text, a partir de la coherència. Malgrat que fets i conclusió concordin, malgrat que la justificació sigui acceptable, si l'argumentació no és rellevant, un text argumentatiu no és vàlid, perquè no resulta coherent. L'argumentació proporciona les eines retòriques per convèncer o persuadir els altres, cosa que, en últim terme, és la finalitat d'elaborar un text argumentatiu. Les raons produïdes han de ser pertinents basant-se en el mateix cos de coneixements que permet acceptar la justificació, però es refereixen a altres aspectes relacionats amb els fets i que reforcen l'establiment de la conclusió. Des del punt de vista de l'aprenentatge del raonament científic, potser aquest aspecte és el més complex, perquè cal trobar les raons més rellevants d'entre tots els coneixements que es tenen, poder-les justificar, i que permetin convèncer els altres de manera que els resulti coherent amb el coneixement que tenen. Aquesta és una de les dificultats més importants de l'alumnat (Llorens i De Jaime, 1995) en la producció de textos argumentatius, perquè les raons donades sovint són inconnexes o no estan implicades de forma lògica amb l'afirmació i no es pot establir una línia argumentativa clara. L'alumnat tendeix a incorporar idees científiques que no tenen relació entre elles mateixes (des del punt de vista de l'expert), formulades en termes quotidians, sense conceptes que estructurin l'argumentació. Per aquestes raons, s'analitzen els tres tipus d'arguments per separat, tenint en compte la pertinència respecte a la ciència-tecnologia o al sentit comú, els tipus d'arguments no rellevants i les justificacions $i$ fonamentacions (implícites o explícites).

\section{Exemplificació}

Ja s'ha esmentat que l'exemplificació és la relació entre la ciència-teconologia i la vida quotidiana, en la qual l'alumnat ha de trobar l'aplicació del coneixement científic que està posant en joc en l'argumentació. En aquest 
Figura 5

Xarxa de l'ítem: Validesa formal del text.

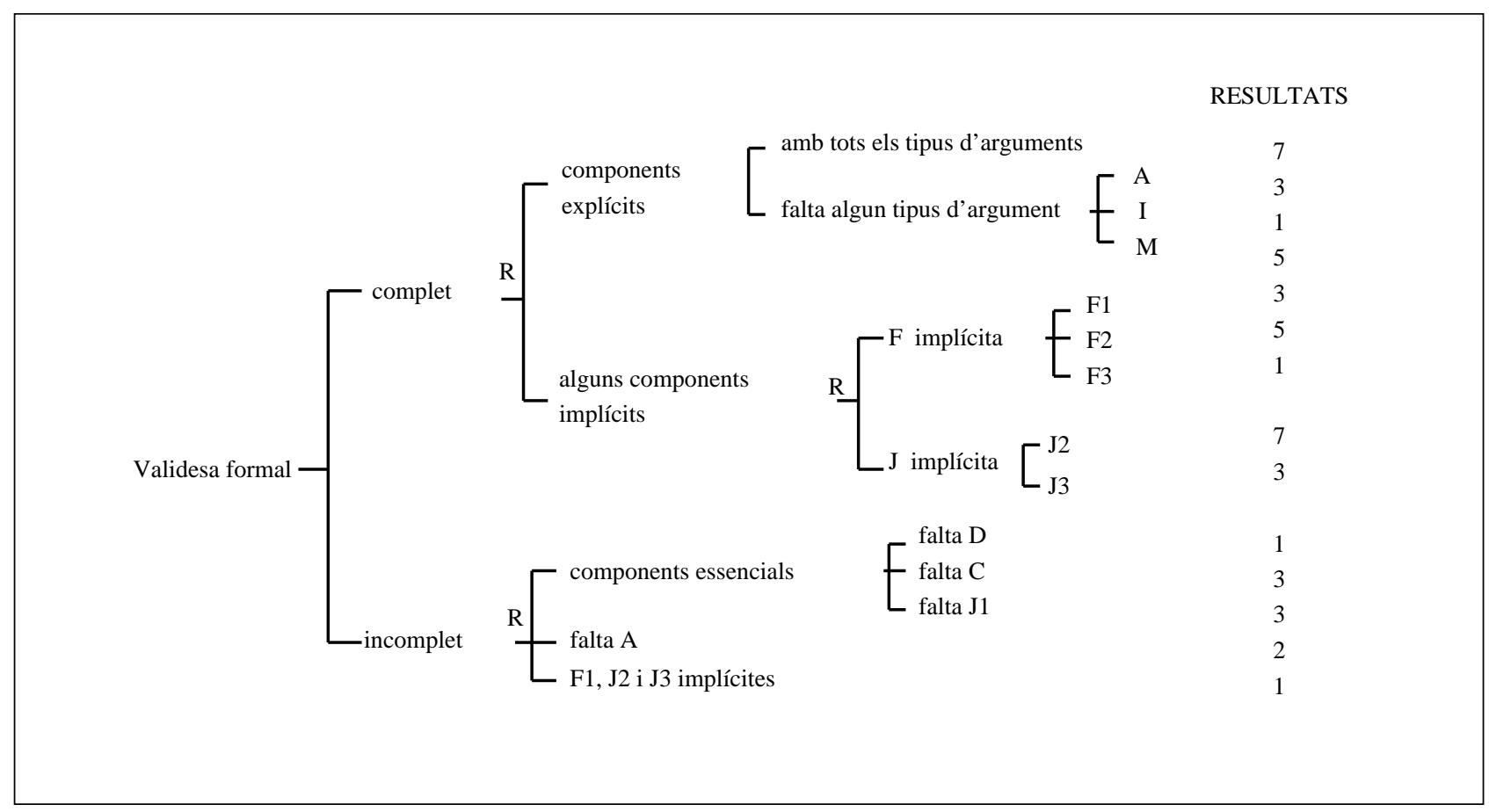

cas, la relació hauria de raure en els diversos usos que tenen les diferents tècniques de conservació dels aliments. Per tant, s'analitza la seva pertinència en els mateixos termes en què s'han analitzat els arguments, respecte de la fonamentació científico-tècnica o del sentit comú. I per altra banda, s'ha analitzat si l'exemplificació és una conseqüència lògica de la conclusió o està relacionada amb altres aspectes.

\section{RESULTATS DE L’ANÀLISI I DISCUSSIÓ DE LES DADES}

A continuació s'analitzen les produccions de l'alumnat en funció dels ítems descrits en l'apartat anterior.

\section{Validesa formal del text}

El primer que cal destacar, a partir de les dades recollides a la xarxa sistèmica (Fig. 5), és que la gran majoria de produccions són vàlides formalment. En concret, hi ha quinze textos complets. En segon lloc, constatem que només, en un dels textos, hi falta l'inconvenient i és l'argument que està més justificat.

De les cinc produccions que són incompletes i, per tant, no són vàlides formalment, només, en un cas, hi falta el component principal: el fet (o les dades): «L'emmagat- zematge de l'envasat al buit és una tècnica que quan es treu de la fàbrica els productes, si no es posen al refrigerador, es fan malbé.» Analitzant a fons aquest text, es pot comprovar que en realitat l'alumne considera el mateix fet com un inconvenient de la tècnica de conservació i, per tant, el formula com a tal perquè no és capaç de distingir estrictament el fet de la seva interpretació com a inconvenient. Consequient, amb aquesta dificultat, aquest alumne tampoc no formula cap avantatge de la tècnica. En tres casos de textos incomplets, hi manca la conclusió i, a més, la justificació principal, i alguna justificació i fonamentació secundàries. En un, l'argumentació està ben elaborada però, senzillament, falta formular la conclusió final. En els altres dos, els arguments utilitzats no són pertinents, són ambigus o incongruents entre ells mateixos; per tant, és lògic que els resulti difícil formular una conclusió (Fig. 6).

Només en un cas de text incomplet, hi manca solament la justificació principal. És un text complex que segueix una argumentació que no és pertinent amb el fet inicial establert, que es refereix a una altra variable. La tesi formulada a l'inici queda sense connexió amb la resta de l'argumentació i, per tant, sembla lògic que no estigui justificada.

Per últim, és destacable el fet que, dels cinc textos que no són vàlids formalment, només un és un text escrit; la resta són textos orals -improvisats durant la realització del joc de rol. Dels quinze que són vàlids formalment, la 
majoria són textos escrits i només cinc són orals. Per tant, pel que fa referència a la formulació i explicitació dels components del text argumentatiu, sembla que el fet d'escriure'ls ajuda l'alumnat a ser capaç de tenir-los en compte.

\section{Seqüència textual}

De l'anàlisi d'aquest ítem, el primer que cal destacar és que la majoria de les produccions (tretze) presenten connectors -sense tenir en compte si són adequats o no,
Figura 6

Exemple de l'esquema d'un text sense conclusió.

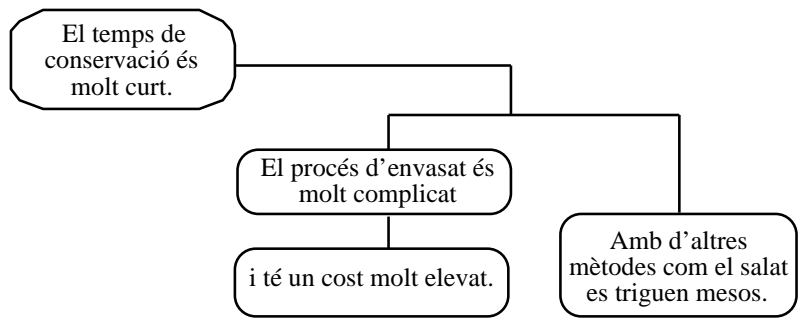

Figura 7

Xarxa de l'ítem: Connectors.

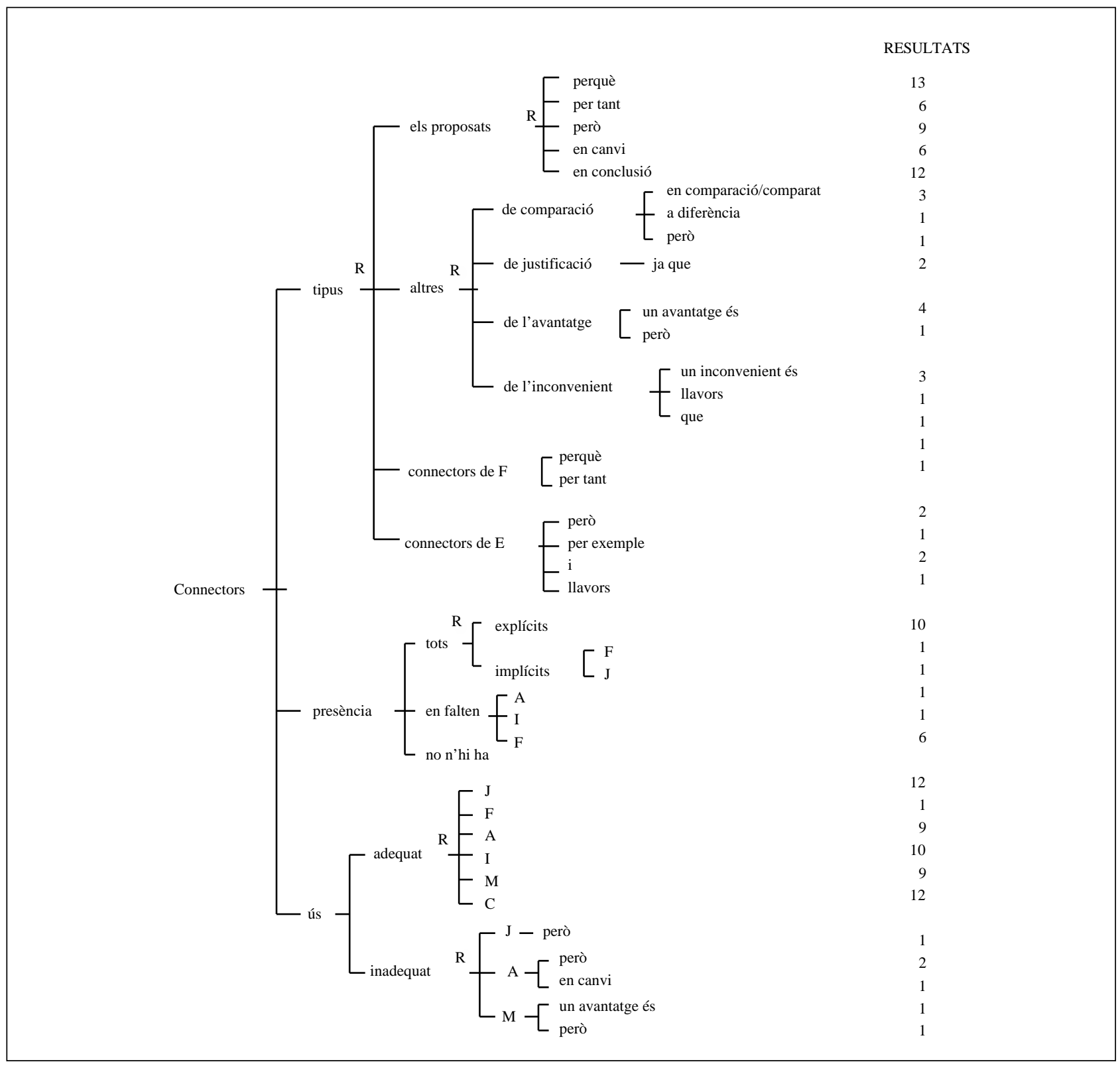


implícits o explícits- i, per tant, a aquest nivell, es pot dir que constitueixen seqüències textuals. Deu presenten justificacions i fonamentacions de la majoria dels enunciats o components del text. Les set produccions que no tenen connectors, ni de forma implícita ni explícita, no es consideren seqüències argumentatives. De fet, si s'analitzen aquestes produccions a fons, es pot comprovar que són oracions desconnexes de significat entre si. Per altra banda, només sis seqüències presenten el component «exemplificació», perquè als alumnes els costava força d'establir aquesta relació de la conservació dels aliments amb les aplicacions de la vida quotidiana. Segurament aquesta dificultat es pot explicar perquè el joc de rol es realitzava en un context escolar o, senzillament, pel fet que, en el text discutit com a model, l'exemple estava situat a la part final del text $\mathrm{i}$ l'alumnat podria valorar que no era necessari esforçarse per incloure l'últim argument. Pel que fa a la relació entre l'argument avantatge i l'argument inconvenient vam observar que la majoria de les seqüències elaborades per l'alumnat eren força semblants a la que se'ls va presentar a través del text-exemple.

\section{Connectors}

En aquest ítem (Fig. 7) s'analitza en primer lloc el tipus de connectors que va utilitzar l'alumnat en les seves produccions. És destacable el fet que la gran majoria dels connectors són els mateixos que els proposats per les professores en el text discutit com a exemple. El connector causal utilitzat per excel-lència és perquè, tant per a les justificacions com per a les fonamentacions; $\mathrm{i}$ alguns utilitzen ja que. Els dos tipus de connectors consecutius més utilitzats són per tant, i en conclusió, i algunes variacions. Els connectors adversatius són els més variats: els més usats són però, per introduir els inconvenients, i en canvi, per a les comparacions. Alguns dels introductoris de comparació són: en comparació, comparat amb, a diferència de, però. Alguns dels introductoris dels inconvenients són que i llavors. Dos exemples: $a$ ) «Llavors l'has de descongelar bé perquè si no mates les cèl-lules amb els cristalls aquells que vam dir.»b) «[...] però a diferència de l'assecat, per exemple, és que es pot envasar al moment.»

Els connectors de les exemplificacions els utilitzen en funció del tipus d'oració que introdueixen, és a dir, si no és cap consequiència de la conclusió, sinó que és una idea afegida a l'argumentació, usen llavors, per exemple, o la conjunció $i$ coordinada: «Llavors les cambres de congelació poden tenir força sortida de camions que poden portar el producte a molts llocs.»

A banda dels tipus de connectors que utilitza l'alumnat, cal destacar que les dificultats d'identificació dels diferents components del text argumentatiu fan que aquell tingui la necessitat d'explicitar-los a través de connexions del tipus: «Però a diferència de l'assecat, per exemple, és que es pot envasar al moment (i això seria una comparació).» Aquesta explicitació del tipus de component que s'està formulant es produeix en els textos orals improvisats. Cal destacar, igualment, que aquests textos són els que presenten més dificultats de coordinació i subordinació, en definitiva, per establir connexions lògiques explícites.

Per tant, quant a l'ús dels connectors, podem dir que el fet d'escriure els textos ajuda a l'alumnat a explicitar i precisar un ús més adequat per tal d'introduir els diferents components de l'argumentació.

\section{Concordança fets-conclusió}

El fet més destacable de l'anàlisi d'aquest ítem (Fig. 8) és que només en tres de les produccions trobem una concordança entre la tesi formulada inicialment i la conclusió establerta finalment. Una d'aquestes conclusions s'estableix en els termes científico-tecnològics que l'alumne utilitza en tota la seva argumentació: «El temps de conservació dels aliments congelats és des de tres mesos fins a un any [...] La congelació dels aliments és una bona tècnica per conservar els aliments durant força temps

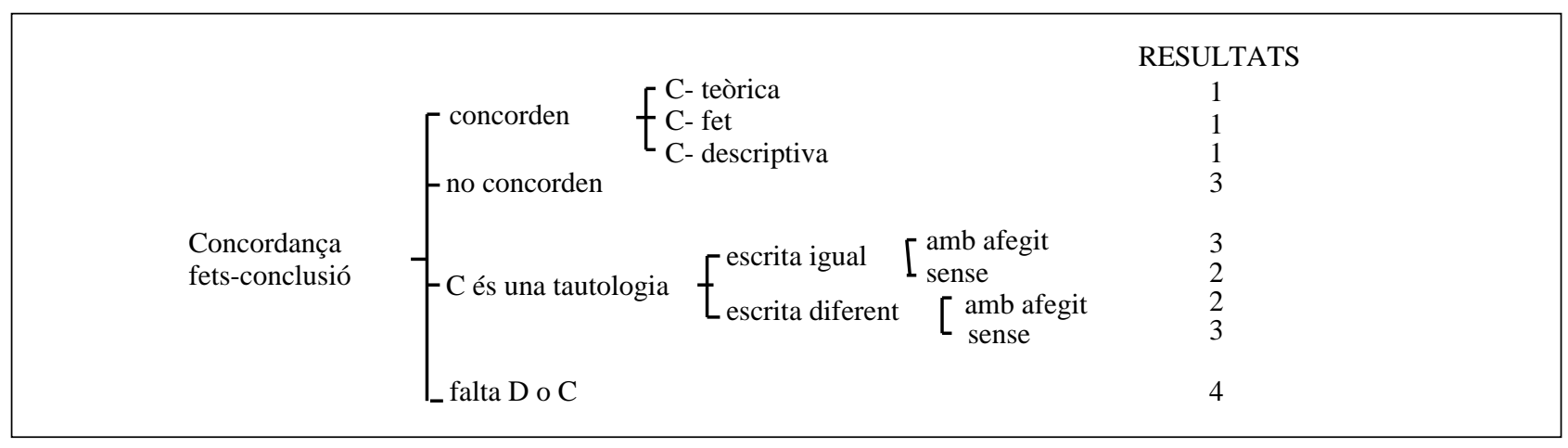


[que costa molt poc de preparar i no varia les seves característiques organolèptiques i nutritives].» La segona part de la conclusió (entre claudàtors) l'afirma sense haver tingut en compte, en cap moment de l'argumentació escrita, la seva justificació teòrica. Hi fa referència perquè són algunes de les orientacions que s'havien discutit durant la realització de l'activitat i alguns companys les havien utilitzat en els seus textos. Aquest és un exemple que mostra que, si bé des de la lògica formal, l'última frase és una conseqüència sense referent teòric, tenint en compte el context de l'activitat, l'hem de considerar com a coherent $\mathrm{i}$ vàlida de forma implícita.

Un altre alumne escriu una conclusió que només fa referència al fet inicial, sense tenir en compte les raons que ha exposat, i se sobreentén el significat del que conclou, malgrat que no ho acabi de dir: «Amb el sistema de conservació de l'enllaunat, l'aliment pot durar des d'un fins a tres anys. [...] L'enllaunat és una bona tècnica.» La tercera producció en què concorden fets $\mathrm{i}$ conclusió és d'una alumna que formula la conclusió en termes bàsicament descriptius: «L'emmagatzematge del pernil salat necessita un lloc a la fàbrica, bueno, dues sales bastant grans. [...] És un bon sistema per assecar gran quantitat de pernils i que en principi és barat: depèn de la temperatura exterior.»

S'han trobat tres produccions que parteixen d'una bona identificació del fet inicial, però que arriben a una conclusió que no hi concorda (Fig. 9). En els tres casos, l'argumentació es basteix sobre alguns aspectes que no són pertinents, ja que es refereixen a altres variables que afecten les dades. Per tant, la conclusió a la qual arriben concorda d'alguna manera amb alguns dels enunciats de l'argumentació, però no amb la tesi inicial.
Aquest és un cas on es detecta una altra de les dificultats que tenen els estudiants: creure que allò més rellevant és allò que està d'acord amb el model individual i seleccionar incorrectament les evidències i no distingir-les de les interpretacions.

Deu conclusions de les produccions dels estudiants són tautologies de la tesi inicial, bé escrites exactament amb les mateixes paraules, bé amb paraules diferents. Algunes, a més, aporten algun comentari afegit. En tots els casos, el fet està ben identificat i formulat, les argumentacions varien segons cada text, però tots acaben concloent un enunciat que es refereix al mateix fet: «El temps de preparació és molt curt. [...] El temps de preparació és molt curt, amb altres mètodes es triguen mesos.» Aquesta és una altra de les grans dificultats de l'alumnat: diferenciar entre els fets que s'han d'argumentar de la teoria que hi ha al darrere i que els conduiria a una conclusió adequada, en lloc d'una tautologia.

\section{Acceptabilitat de la justificació principal}

Gairebé la meitat de les justificacions principals són pertinents (Fig. 10): una en relació amb la vida quotidiana; set en relació amb la ciència-tecnologia; i una altra a partir dels dos tipus de raons.

Les dues justificacions basades en el sentit comú de la vida diària són del mateix tipus: «La sortida al mercat dels productes congelats és bona. [...] Perquè en estar tallats i congelats no s'ha de fer cua, és més higiènic $i$ ja està tallat a trossos.» Les vuit justificacions que són pertinents en l'àmbit científico-tecnològic tenen diferent força, segons a quin nivell del cos de coneixements

Figura 9

Exemple de l'esquema d'un text analitzat en què fets i conclusió no concorden.

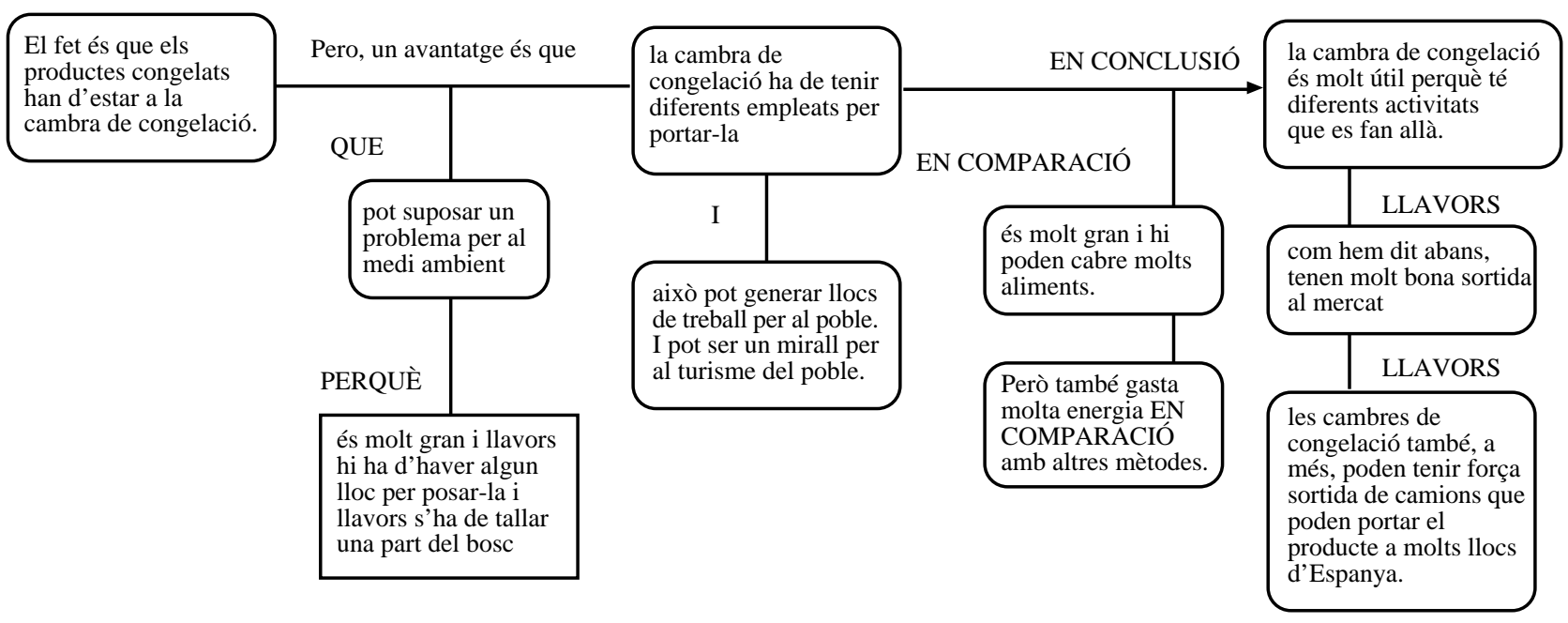


teòrics es refereixen, és a dir, que varien en funció del valor epistemològic que tenen per convèncer els altres perquè eliminen amb major o menor grau la resistència a les objeccions que els puguin fer: «La conservació del pernil salat dura entre un i dos anys si el pernil no ha estat encetat. [...] Perquè, quan salem, deshidratem i els microorganismes no poden créixer.» Aquest primer exemple mostra una justificació principal que té molta força perquè explicita la causa principal de la llarga conservació del pernil salat (el fet), de manera que no hi ha lloc per a possibles objeccions. A més a més, quan formula l'afirmació inicial, concreta que ell es refereix a la conservació del pernil quan encara no s'ha encetat.

Un segon exemple: «L'emmagatzematge del pernil salat necessita un lloc a la fàbrica, bueno, dues sales bastant grans. [...] Una airejada per a l'assecat natural, i l'altra per fer-ho amb escalfor artificial.» Aquesta justificació no té tanta força perquè no explicita el perquè calen els dos tipus de sales, només descriu la utilitat de cada una. En ambdós casos els fets estan ben identificats i les evidències no estan subjectes a la interpretació, però la selecció del que és més rellevant varia en funció del model escollit per construir la justificació.

Per altra banda, cal destacar que, excepte dos casos, la resta de justificacions acceptables es troba en les produccions escrites. Es pot dir que, en aquest cas, el fet d'haver pensat i escrit les idees ajuda l'alumnat a justificar correctament, com ja s'ha vist en l'anàlisi d'altres ítems. Vuit produccions més no justifiquen de forma acceptable, a causa de diferents raons de pertinència; la meitat de les quals són tautologies de l'afirmació inicial: «Amb l'enllaunat es menja directament i no cal fer res abans de menjar-lo. [...] Només cal obrir la llauna i ja està.»
Pel que fa als criteris que validen la justificació, proporcionats per la seva fonamentació, cal dir, en primer lloc, que manquen en la majoria dels textos de l'alumnat. Les justificacions principals que es refereixen a la ciènciatecnologia estan fonamentades, tant explícitament com implícita, també des de la perspectiva de la ciènciatecnologia $i$, per tant, validen la pertinència de la justificació: «Perquè, quan enllaunem un aliment fem que no hi hagi aire. [...] I, per tant, els microorganismes no poden créixer.»

Una de les justificacions, que es refereix a la vida quotidiana, també està fonamentada seguint el mateix criteri de forma coherent, tot i que aquest cas és especial perquè l'alumne elabora tant la justificació com la fonamentació basant-se en els dos tipus de pertinència: «Perquè és higiènic [ciència-tecnologia] i a la gent li és còmoda la compra [vida quotidiana]. [...] En ser hermètic no està exposat als microorganismes de l'exterior [ciència-tecnologia]; la gent l'agafa, el mira, el deixa... i la compra es pot fer per selecció [vida quotidiana].»

Per últim, cal destacar que en cap cas no s'ha trobat una fonamentació basada en el sentit comú que sigui incoherent amb la justificació.

\section{Rellevància de l'avantatge}

En primer lloc, cal destacar que s'han trobat més avantatges que no són pertinents per diferents raons, que els que sí que ho són. Només dues produccions formulen avantatges rellevants quant a la ciència-tecnologia, $i$ quatre més, en relació amb la vida quotidiana. El següent exemple és d'un text que formula l'avantatge, en termes de la utilitat en la vida diària, de salar dels aliments:

Figura 10

Xarxa de l'ítem: Acceptabilitat de la justificació principal.

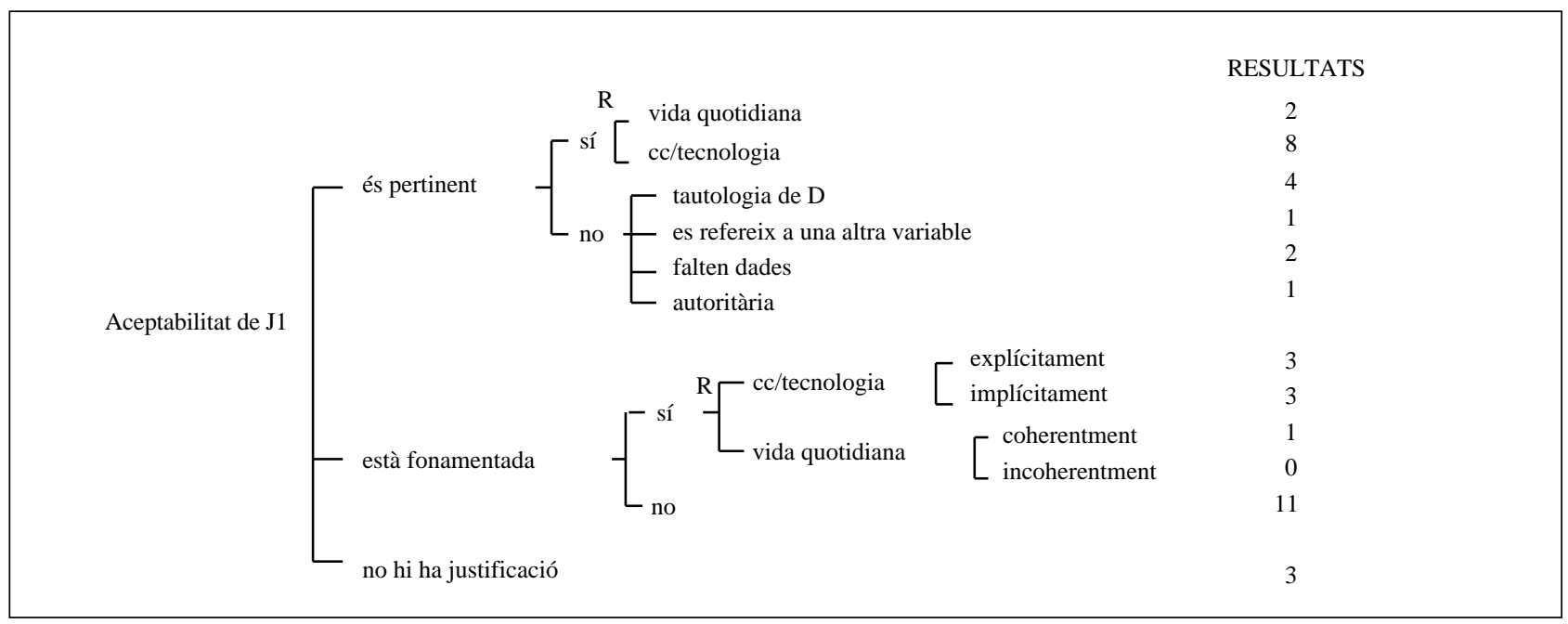


Figura 11

Xarxa de l'ítem: Rellevància de l'inconvenient.

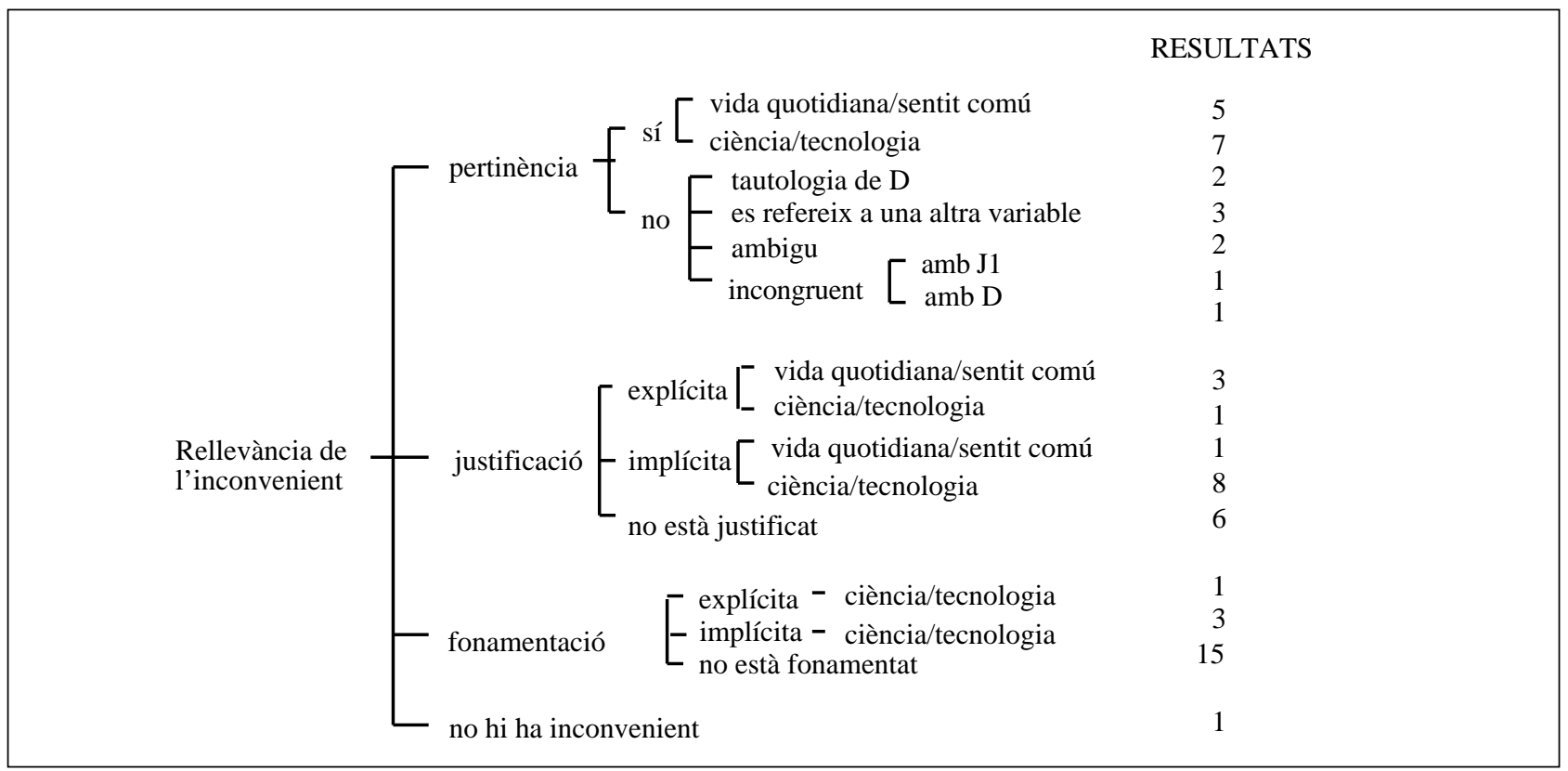

«Per tant, podem menjar un mateix aliment [pernil] amb un sabor completament diferent.» Un altre exemple és d'un text que elabora un avantatge en termes de ciènciatecnologia en relació amb la conservació dels aliments congelats: «Per tant, anul·lem la possibilitat que l'aliment es podreixi i es faci malbé.»

En els tipus d'avantatges que no són pertinents es torna a observar que l'alumnat formula tautologies o elabora idees que són ambigües. Les tautologies, en aquest cas, es refereixen a l'afirmació inicial o a la justificació, que és el component anterior en la seqüència textual: «Perquè, en estar tallats i congelats, no s'ha de fer cua, és més higiènic i ja està tallat a trossos [justificació]. Per tant, és més pràctic i higiènic [avantatge].»

\section{Rellevància de l'inconvenient}

Excepte el text que no té l'inconvenient, en la resta de produccions (Fig. 11), els arguments elaborats d'aquest tipus són pertinents en la majoria dels casos, tant amb relació a la ciència-tecnologia, com amb relació a la vida quotidiana, i en dos dels casos són pertinents amb relació amb als dos tipus de coneixement: «El cost global dels productes congelats és elevat. [...] El cas és que les famílies amb pocs recursos econòmics no podran accedir a grans quantitats de congelats.» En els tipus d'inconvenients que no són pertinents s'observen les mateixes categories que s'han analitzat en l'avantatge: tautologies de la tesi inicial, enunciats que es refereixen a una altra variable o que són ambigus. A més, en aquest cas apareixen arguments que presenten incongruències amb l'afirmació inicial o amb la justificació principal.

Quant a les justificacions dels inconvenients, en la majoria de les produccions s'han pogut considerar com a implícites. Les que són explícites, tant es refereixen al context de la ciència-tecnologia $(\mathrm{a})$ com al context de la vida quotidiana (b): a) «Un aliment congelat no te'l pots emportar d'excursió. [...] Perquè, clar, l'has de cuinar.» b) «Un desavantatge és que hi ha un temps molt... que no pots assecar. [...] Ho has de fer amb escalfor artificial, doncs... que gastes massa i llavors el pressupost de la fàbrica surt més alt.»

Per últim, cal esmentar que només en un dels textos apareix una justificació fonamentada de l'inconvenient de forma explícita; i en un altre cas, s'ha considerat com a implícita. En la resta de produccions no hi ha aquesta fonamentació.

\section{Rellevància de la comparació}

Les comparacions explicitades, tant les pertinents com les que no ho són, han estat formulades amb relació a la ciència-tecnologia. La gran majoria de les comparacions establertes es refereixen a la mateixa variable: que uns productes tractats amb una determinada tècnica es conserven durant més temps que amb un altre mètode. Els alumnes que defensen les tècniques que permeten conservar durant més temps els aliments destaquen aquest 
fet per contraposar-lo amb els mètodes que permeten una conservació de més curta durada: «En canvi, altres mètodes, com la refrigeració, no eliminen tots els microorganismes i els que queden poden reproduir-se [congelació].» I els segons exalten la rapidesa del procés de conservació: «En altres mètodes es triguen mesos; aquest és instantani [envasat al buit].»

Cal esmentar que, mentre els estudiants estaven elaborant les seves produccions, es va detectar la gran dificultat que tenien per establir comparacions lògiques i coherents, perquè tendien a falsejar les evidències, de manera que exaltaven el mètode de conservació defensat amb idees que anaven més enllà dels límits de la pròpia tècnica. Els arguments resultants eren, en la majoria dels casos, autoritaris (perquè és la millor tècnica) o fal-làcies. Per il-lustrar-ho, mostrem la següent transcripció de la discussió d'un argument:

C. -Amb l'enllaunat s'ha de vigilar abans de menjar; o sigui, que la llauna pot estar en mal estat. $\mathrm{O}$ sigui: si la llauna està inflada $\mathrm{o}$ així, llavors no l'hem de comprar.

L. -Però això no és culpa nostra, és de la fàbrica.

C. -Però, tu ets la fàbrica!

L- -Però fem controls de qualitat, a la nostra empresa.

Per altra banda, en els tipus de comparacions que no són pertinents es tornen a observar les mateixes categories que s'han analitzat en els altres dos tipus d'arguments: tautologies de la tesi inicial, enunciats referits a altres variables o ambigus. Quant a les justificacions de les comparacions, cal esmentar que només una és explícita, tres s'han considerat implícites, però la gran majoria no les produeixen. De la mateixa manera, gairebé cap no està fonamentada.

\section{Exemplificació}

De les sis produccions que formulen l'exemplificació (Fig. 12), una fa referència explícitament als coneixements sobre ciència-tecnologia que l'alumne havia après durant la unitat didàctica: «En aquest mètode no s'ha afegit cap tipus d'ingredient, que poden fer variar el gust o el color.» Excepte en un dels casos, la resta d'exemplificacions fa referència a diversos aspectes del sentit comú, i de forma significativa: «Llavors, com hem dit abans, tenen molt bona sortida al mercat, llavors les cambres de congelació també; a més, poden tenir força sortida de camions que poden portar el producte a molts llocs.»

El següent exemple és el cas d'una proposició adversativa que desenvolupa una funció molt important en l'argumentació de l'alumne per tal que la conclusió sigui acceptada pels altres: «En conclusió, l'envasat al buit requereix una infraestructura molt complexa i un cost elevat. Però tota aquesta despesa s'acaba compensant amb l'èxit de les vendes.»

\section{CONCLUSIONS I CONSEQÜÈNCIES DI- DACTIQUES}

Els resultats del nostre estudi mostren que, pel que fa al patró estructural o anatomia del text argumentatiu, la majoria de les produccions dels estudiants són seqüències textuals argumentatives completes o gairebé, amb quasi tots els connectors del tipus lògico-argumentatius explícits. En canvi, les grans dificultats les trobem en analitzar la fisiologia dels textos.

Figura 12

Xarxa de l'ítem: Exemplificació.

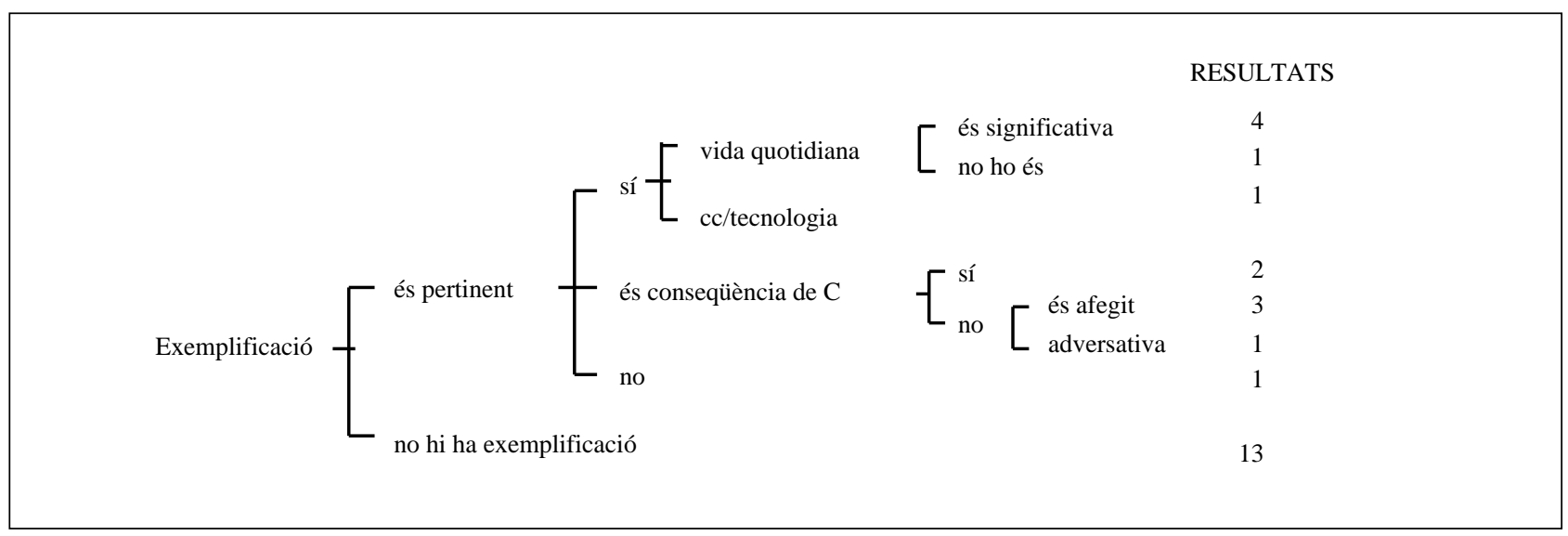


Així, trobem que els estudiants no seleccionen arguments rellevants i pertinents des del punt de vista científic -fet que posa de relleu que no s'ha representat adequadament l'objectiu de l'activitat- i tampoc no saben anticipar ni planificar les estratègies i operacions necessàries per a la producció del text argumentatiu. Tenen dificultats per seleccionar les evidències significatives perquè cerquen raons en les seves preconcepcions més que no pas en els models de la ciència, en no distingir entre els fets i les seves interpretacions, en l'establiment d'inferències no justificades i en l'afirmació de conseqüències sense tenir en compte el context teòric. D'altra banda, en no tenir la tasca planificada, l'alumnat té moltes dificultats per arribar a una conclusió significativa que concordi amb el fet enunciat; problema molt lligat també a la falta d'autoregulació de tot el procés.

Podríem afirmar, doncs, que el conjunt de l'alumnat ha intentat «complir» amb la demanda del professorat -escriure una argumentació- preocupant-se més pel fet que les seves produccions continguessin els elements estructurals necessaris d'una bona argumentació que no pas pel fet que els raonaments seleccionats fossin significatius i tinguessin validesa científica. Segurament aquesta manera d'afrontar la realització de la tasca li requeria menys esforç, ja que només havia de pensar en els aspectes «formals», però l'anàlisi també posa de manifest que cal avaluar i regular la representació que l'alumnat fa dels objectius de l'activitat a realitzar, especialment si té subobjectius aparentment diferenciats, com ara expressar raonaments convincents i escriure'ls (o dir-los) de forma adequada.

Pel que fa a la pròpia execució de la tasca, és a dir, a l'hora d'escriure, la majoria dels textos realitzats reflecteixen la naturalesa argumentativa, perquè deixen entreveure la intencionalitat $\mathrm{i}$ estan adaptats al nivell de coneixements dels receptors per tal que els puguin entendre. Segurament, aquesta és una explicació del perquè s'ha constatat l'elevat ús de les tautologies en argumentar la utilització de variables que no són rellevants, la producció d'enunciats ambigus o incongruents i l'aplicació d'arguments autoritaris o amb falta de dades que permetin de validar-los. Tant les justificacions com les fonamentacions (sempre coherents) estan formulades tant en termes del coneixement teòric ciènciatecnologia, com en relació amb el coneixement empíric construït a partir de la vida quotidiana. L'alumnat té moltes dificultats per distingir el nivell de significats d'allò que és quotidià i d'allò que és científic, de manera que en un mateix text es barregen tots dos tipus de coneixement. D'igual manera, en una mateixa producció coexisteixen raons $i$ arguments pertinents i coherents, $i$ d'altres que no són rellevants.

En comparar els textos escrits amb els orals, es constata que, en general, en els primers s'utilitzen els substantius de forma més precisa i subjectes més abstractes enfront de l'ús de termes comodí del llenguatge quotidià utilitzats en els segons. També en els primers s'expliciten més les relacions lògico-argumentatives i el text està més estructurat enfront de les relacions de tipus continu- atiu i menys estructurades de l'oral. Una altra de les diferències és que els textos escrits utilitzen més les oracions passives i impersonals en un llenguatge més descontextualitzat enfront de l'ús indicatiu i les formes personals primera del singular i del plural dels textos orals.

Tot i la relativa pobresa teòrica de l'argumentació expressada, els textos que varen produir aquestes noies $\mathrm{i}$ nois estaven més estructurats que els anteriors, és a dir, es va notar una millora en l'objectiu que l'alumnat havia percebut com a important. Tanmateix, continuem plantejant la hipòtesi i el repte segons el qual, per tal que l'alumnat progressi en el coneixement científic, ha d'arribar a reconèixer que tan important és intentar millorar la qualitat de les idees expressades com la forma d'expressar-les, i que ha d'anar aprenent a planificar totes dues vessants de forma conjunta.

Per aconseguir aquest objectiu caldrà dissenyar processos didàctics molt més llargs que l'activitat que va donar lloc a aquest treball. Tot això representa un canvi en les maneres com l'alumnat creu que s'aprenen les ciències i en la valoració sobre la importància del llenguatge en el seu aprenentatge; i, ja se sap, que els canvis en les concepcions, en els valors i en les pràctiques no són fàcils. Per promoure aquests canvis creiem que el marc de referència elaborat i la metodologia d'anàlisi dissenyada poden ser una bona eina, tant per ensenyar l'alumnat a elaborar bons textos argumentatius en el camp de la ciència escolar com per valorar les dificultats amb què es troben.

D'una banda, considerem que l'instrument utilitzat per a l'anàlisi (Fig. 4) també pot ser utilitzat per l'alumnat per reconèixer les característiques d'aquest tipus de textos, per anticipar i planificar les operacions necessàries i per avaluar i regular-ne la qualitat, aspectes, tots fonamentals en la realització d'activitats per aprendre (Jorba i Sanmartí, 1996; Veslin i Veslin, 1992). Segurament no es tracta tant de donar l'instrument ja elaborat com de promoure que els estudiants construeixin el seu -una «base d'orientació»- a partir de l'anàlisi de bons textos argumentatius, bé elaborats pel professorat, bé per altres companys, o bé que es trobin en llibres. L'instrument-model pot ser un referent per al professorat i també per a l'alumnat a fi d'avaluar i regular el seu.

D'altra banda, el tipus d'anàlisi realitzat i les xarxes sistèmiques dissenyades també poden ser útils al professorat (i al mateix alumnat) per avaluar la qualitat dels textos argumentatius produïts, i reconèixer els principals tipus de dificultats. Això pot permetre orientar més específicament l'activitat a l'aula cap a la superació d'aquestes dificultats, que poden ser diferents per a cada noi i noia.

Valorem que tot procés d'ensenyament i aprenentatge -i aquest cas de l'elaboració de textos científics argumentatius n'és només una mostra- és fonamentalment un procés de regulació contínua: de l'ensenyament, perquè el professorat ha de poder identificar les necessitats de l'alumnat, i proporcionar-li eines per ajudar-lo a satisfer-les; i de 
l'aprenentatge, perquè el propi alumnat ha de reconèixer les seves dificultats i trobar camins per superar-les. Creiem que és important continuar investigant sobre les formes de respondre a aquests reptes, molt especialment en el camp de l'expressió de les idees de la ciència.

\section{REFERÈNCIES BIBLIOGRÀFIQUES}

ADAM, J.M. (1992). Les textes: types et prototypes. París: Nathan.

BLISS, J. et al. (1983). Qualitative Data Analysis for Educational Research. A guide to uses of systemic networks. Londres: Croom Helm.

CALSAMIGLIA, H. i TUSÓN, A. (1999). Las cosas del decir. Barcelona: Ariel.

CUSTODIO, E. i SANMARTÍ, N. (1997). Aprendre a justificar científicament: el cas de l'origen dels éssers vius. Temps d'Educació, 18, pp. 17-41.

DIJK, T.A. Van (1978). La ciencia del texto. Barcelona: Paidós.

DRIVER, R. i NEWTON, P. (1997). Establishing the norms of scientific argumentation in classrooms. Document preparat per presentar-lo a la Conferència ESERA, del 2 al 6 de setembre de 1997. Roma.

DUSHL, R.A. (1997). Renovar la enseñanza de las ciencias. Importancia de las teorías y su desarrollo. Madrid: Narcea.

GIERE, R. (1999). Un nuevo marco para enseñar el razonamiento científico. Enseñanza de las Ciencias, núm. extra, pp. 63-69.

HALLDÉN, O. (1988). The evolution of the species: pupil perspectives and school perspectives. International Journal of Science Education, 10(5), pp. 541-552.

IZQUIERDO, M. i SANMARTÍ, N. (1998). Ensenyar a llegir $i$ a escriure textos de ciències de la naturalesa, en Jorba, J., Gómez, I. i Prat, A. (eds.).Parlar i escriure per aprendre. Us de la llengua en situació d'ensenyament-aprenentatge de les àrees curriculars, pp. 210-233. Bellaterra: ICE de la UAB

JIMÉNEZ, M. (1998). Diseño curricular: indagación y razonamiento con el lenguaje de las ciencias. Enseñanza de las Ciencias, 16(2), pp. 203-216.

JORBA, J. (1998). La comunicació i les habilitats cognitivolingüístiques, en Jorba, J., Gómez, I. i Prat, A. (eds.). Parlar $i$ escriure per aprendre. Ús de la llengua en situació d'ensenyament-aprenentatge de les àrees curriculars, pp. 37-58. Bellaterra: ICE de la UAB.

JORBA, J. i SANMARTÍ, N. (1996). Enseñar, aprender y evaluar: un proceso de regulación continua. MEC-CIDE.

[Article rebut al setembre de 1999 i acceptat al març de 2000.]

\section{NOTA}

1. Citat per Driver i Newton (1997).

\section{AGRAÏMENTS}

Volem agrair els comentaris i suggeriments de les professores Mercè Izquierdo i Àngels Prat en l'elaboració d'aquest article.

La recerca en la qual es basa el contingut d'aquest treball ha estat aprovada i finançada pel Ministerio de Educación y Cultura a través de la convocatòria del CIDE d'ajuts a la investigació educativa.

LAYTON, D. (1992). Science and technology teacher training and the quest for quality, en Layton, D. (ed.). Innovations in Science and Technology Education, 4. París: UNESCO.

LEMKE, J.L. (1997). Aprender a hablar ciencia. Lenguaje, aprendizaje y valores. Barcelona: Paidós.

LLORENS, J.A. i DE JAIME, M.C. (1995). La producción de textos escritos en el aprendizaje de las ciencias. Bases para un programa de investigación. Comunicación, Lenguaje y Educación, 25, pp. 113-132.

OGBORN, J., KRESS, G., MARTINS, I. i McGILLICUDDY, K. (1998). Formas de explicar. La enseñanza de las ciencias en secundaria. Madrid: Aula XXI-Santillana.

PRAT, A. (1998). Habilitats cognitivo-lingüístiques i tipologia textual, en Jorba, J., Gómez, I. i Prat, A. (eds.). Parlar $i$ escriure per aprendre. Ús de la llengua en situació d'esenyament-aprenentatge de les àrees curriculars, $\mathrm{pp}$. 59-84. Bellaterra: ICE de la UAB.

PUJOL, R.M., SARDÀ, A. i RODRÍGUEZ, A. (1998). La conservación de los alimentos, en Pujol, R.M. i Sanmartí, N. (coords.). Guía Praxis para el profesorado de ESO. Ciencias de la naturaleza, pp. 96-104. Barcelona: Praxis.

SANMARTÍ, N. (1997). Enseñar a elaborar textos científicos en las clases de ciencias. Alambique, 12, pp. 51-61.

SANMARTÍ, N., IZQUIERDO, M. i GARCÍA, P. (1999). Hablar y escribir. Una condición necesaria para aprender ciencias. Cuadernos de Pedagogía, 281, pp. 54-58.

SARDÀ, A. (1999). Una estratègia per ensenyar a argumentar a les classes de ciències, en Borràs, A., Jorge, J., Beltran, T.,Tarruella, R. i Mata-Perelló, J.M. (eds.). Recerca i innovació a l'aula de ciències de la naturalesa, pp. 519-530. Manresa: UPC.

SUTTON, C. (1997). Ideas sobre la ciencia e ideas sobre el lenguaje. Alambique, 12, pp. 8-32.

TOULMIN, S.E. (1993). Les usages de l'argumentation. París: PUF. (1a ed. The uses of Argument, 1958).

VESLIN, O. i VESLIN, J. (1992). Corregir des copies. París: Hachette Éducation. 